\title{
Peran Negara dalam Hubungan Tenaga Kerja di Indonesia
}

\author{
Subijanto \\ subijanto2010@gmail
}

\begin{abstract}
ABSTRAK: Tujuan penulisan ini dimaksudkan untuk mengidentifikasi peran Pemerintah terhadap ketenagakerjaan di Indonesia dan hubungannya dengan organisasi ketenagakerjaan. Permasalahan tenaga kerja di Indonesia sampai saat ini masih belum sirna dari permasalah yang mendasar, yaitu kurang memiliki keterampilan fungsional bagi calon pencari kerja. Era globalisasi menuntut calon pencari kerja mampu berkompetisi dan memiliki kompetensi yang memadai sesuai dengan persyaratan tuntutan kualifikasi pekerjaan. Dari aspek yuridis formal, tenaga kerja di Indonesia telah dilindungi oleh peraturan perundangundangan, antara lain: 1) UUD Republik Indonesia Tahun 1945 Amandemen, Pasal 27 ayat (2) yaitu "Tiaptiap warga negara berhak atas pekerjaan dan penghidupan yang layak bagi kemanusiaan"; 2) UU Nomor 39/1999 tentang Hak Asasi Manusia, Pasal 38 ayat (1); Ayat (2); Ayat (3); Ayat (4); dan 3) UU Nomor 13/2003 tentang Ketenaga-kerjaan. Dalam aspek pendidikan, Kemdiknas berkewajiban untuk meningkatkan mutu dan relevansi hasil pendidikan, sedangkan Kemenakertrans bertanggungjawab dalam pemberian hak melakukan sertifikasi kompetensi melalui Badan Nasional Standar Profesi (BNSP) dan Lembaga Sertifikat Profesi (LSP).
\end{abstract}

Kata kunci: peran pemerintah, tenaga kerja, keterampilan fungsional, pencari kerja, kualifikasi pekerjaan, kompetensi, sertifikasi kompetensi.

\begin{abstract}
ABSTRAK: The aim of this writing article is to identify the function of the Indonesian Government in relation with Indonesian labor force and the relation of labor force organization. Until now, the foundamental problem of the Indonesian job seekers is lack of functional basic skill. Globalization era, has requirement for every job seekers to have competence and to be able to competitive in certain job qualification requirement. Based on the legal formal, the Indonesian labourforce has been protecting by a number of laws, namely: 1) the amandement of the 1945 Constitutionof the Republic of Indonesia (article,27 sub article (2) stated that every citizen shall have the right job and welfare for human being; 2 ) the act number 39, year 1999 about Human Right an article 38 sub article 1 stated that every citizen, according to potential talent, skill, and smart, shal have the right job. Furthermore, subarticle 2 stated that every people shall have the freedom of choice according to interest and requirement accordingly. Subarticle 3 stated that every people, event women or man to be equal in doing job according to the status of bwckground to get wage in order to be sustainable life; and 3) the act number 13, year 2003 about labour force. In relation with preparation of job seekers the Ministry of National Education (MoNE) has obligation to improve the quality of education and relevance with outcome of education. Meanwhile, the Ministry of Manpower and Transmigration has responsible anda specific task to do the competence of certification through National Board of Proffesional Standard (BNSP) and Institution of Proffesional Standar (LSP).
\end{abstract}

Keywords: government role, workforce, functional skill, job-seekor, competence, job qualification, competence sertification.

\section{Pendahuluan}

Secara sosiologis, posisi pekerja/buruh di Indonesia tidak pernah bebas sebagai pencari kerja yang kurang memiliki keterampilan (unskill labor) yang dipersyaratkan oleh dunia kerja. Di satu sisi, mereka terpaksa bekerja pada orang lain (majikan) dan di sisi lain, majikan memiliki otoritas untuk menentukan persyaratan pekerja/buruh. Dalam konteks hubungan pribadi dengan pribadi (pekerja dengan majikan) disebutnya sebagai kelemahan struktural (Finawati.http://www.pemantauanperadilan.com). Ketidakseimbangan hubungan pekerja/buruh dan majikan tercermin manakala seseorang melamar pekerjaan yang tanpa disadari ia tidak berani menentukan persyaratan kerja, misalnya gaji/upah yang diinginkan. Kondisi ini mengandung risiko manakala majikan/ 
pengusaha tidak menyetujui lamarannya karena ia tidak memiliki posisi bargening yang kuat untuk tawar-menawar dalam menentukan kebutuhannya. Ke depan, hal ini dapat diubah jika persyaratan pekerja/buruh berbasis kompetensi. Standar kompetensi inilah yang seharusnya dikembangkan dan dibakukan sebagai acuan standar persyaratan bagi dunia usaha dan dunia industri (DUDI) dalam merekrut karyawan sesuai kebutuhan.

Dalam hal kompetensi keterampilan/keahlian yang dipersyaratkan pada setiap jenis pekerjaan, Pemerintah telah membentuk suatu badan independen terkait dengan stadarisasi, yaitu Badan Nasional Standarisasi Profesi (BNSP). Badan tersebut diperluas sampai ke tingkat kabupaten/kota yang dikenal dengan Lembaga Sertifikasi Profesi (LSP). LSP-LSP inilah yang memiliki otoritas memberikan sertifikasi kompetensi/profesi bagi setiap calon tenaga kerja yang telah mengikuti ujian kompetensi. Sertifikat kompetensi tersebut semestinya dijadikan dasar penerimaan pekerja/buruh oleh pengusaha/ majikan apabila merekrut tenaga kerja.

Selanjutnya, Pemerintah telah melakukan upaya menciptakan hubungan industrial bagi para pekerja/buruh semenjak awal kemerdekaan, Bahkan, menjelang akhir pemerintahan Presiden Soeharto, Pemerintah mengeluarkan UU Ketenagakerjaan Nomor 25/1997 yang oleh para pekerja/ buruh serta para aktivis HAM ditentang untuk diterapkannya. Hal ini karena dinilai memasung kebebasan para pekerja/buruh untuk berserikat dan menyatakan pendapat. Pada akhirnya, perjuangan penolakan UU tersebut oleh para pekerja/buruh serta para aktivis HAM membuahkan hasil dengan ditundanya pelak-sanaan UU tersebut oleh Presiden Habibi (Kompas, Politik Perburuhan yang "Amburadul", 6 Maret 2000).

Pemasungan kebebasan pekerja/buruh untuk berserikat dan menyatakan pendapat, dapat terlihat pada upaya menyatukan wadah tunggal organisasi pekerja/buruh yang terkesan men-dapat intervensi dari Pemerintah dan pengusaha untuk kepentingan stabilisasi ekonomi. Sebagai salah satu indikator bahwa pemimpin serikat buruh direkrut dan dikuasai oleh salah satu partai politik besar yang waktu itu berkuasa. Pola ini patut diduga sama dengan gaya politik yang diterapkan pada zaman orde lama yaitu mensub-ordinasikan "gerakan buruh/ pekerja " ke dalam politik (anonim, Pentingnya Serikat
Buruh, http://www. (ppi) (ppiindia).

Mengacu pada peraturan perundang-undangan, tanggung jawab Negara terhadap pekerja/buruh di Indonesia pada hakikatnya telah diatur dalam undang-undang, antara lain UUD 1945 Amandemen Pasal 27 ayat (2) yang menyatakan bahwa "Tiaptiap warga negara berhak atas pekerjaan dan penghidupan yang layak bagi kemanusiaan". Selanjutnya, Pasal 34 ayat (2) Negara mengembangkan sistem jaminan sosial bagi seluruh rakyat dan memberdayakan masyarakat sesuai dengan martabat kemanusiaan.

Di samping itu, Undang-Undang Nomor 39, Tahun 1999 tentang Hak Asasi Manusia (HAM) Pasal 38 menyebutkan bahwa 1) Setiap warga negara, sesuai dengan bakat, kecakapan, dan kemampuan, berhak atas pekerjaan yang layak; 2) Setiap orang berhak dengan bebas memilih pekerjaan yang disukainya dan berhak pula atas syarat-syarat pekerjaan; 3) Setiap orang, baik pria maupun wanita melakukan pekerjaan yang sama, sebanding, setara atau sesuai syarat-syarat perjanjian kerja yang sama; 4) Setiap orang, baik pria maupun wanita dalam melakukan pekerjaan yang sepadan dengan martabat kerja upah yang adil sesuai prestasinya dan dapat menjamin kelangsungan kehidupan keluarganya.

Salah satu permasalahan yang masih sering terjadi yaitu belum optimalnya upaya Pemerintah dalam mengimplementasikan produk peraturan perundang-undangan dan menangani kasuskasus ketenagakerjaan di Indonesia. Adapun tujuan penulisan ini dimaksudkan untuk mengidentifikasi peran Pemerintah terhadap ketenagakerjaan di Indonesia dan hubungannya dengan organisasi ketenagakerjaan yang ada.

\section{Kajian Literatur dan Pembahasan Pengertian Hubungan Ketenagakerjaan dan Implikasi di Lapangan}

Hubungan ketenagakerjaan (industrial) atau hubungan perburuan pada hakikatnya merupakan hubungan antarpihak-pihak terkait dengan kepentingan, yaitu antara pekerja (buruh) dan pengusaha (majikan), serta organisasi buruh (serikat pekerja) dan organisasi pengusaha (Kepmenaker Nomor 648/ Men/1985).

Secara harfiah "buruh" dimaknai sebagai orang yang bekerja di bawah perintah orang lain, di mana 
ia menerima upah karena melakukan pekerjaan di perusahaan tempat bekerja. Istilah "buruh" di mata masyarakat Indonesia nampaknya masih terkesan "negatif" di mana istilah tersebut kurang menguntungkan dengan beberapa alasan sebagai penyertanya. Pertama, ada "buruh" berarti ada "majikan" sehingga menimbulkan kesenjangan yang tidak setara dan menimbulkan polarisasi "kasta" atau kelas (golongan status sosial) yang berbeda kepentingan. Kedua, kata "buruh" menimbulkan konotasi sebagai kelompok tenaga kerja dari golongan bawah yang bekerja dengan hanya mengandalkan kekuatan fisik (otot), dan bukan mengandalkan pemikiran (daya nalar). Ketiga, masih ada kesan di masyarakat kata "buruh" teringat dengan ajaran "marxisme" atau setidaktidaknya dengan Gerakan 30 September, di mana saat itu buruh tani sebagai "Barisan Tani Indonesia" sebagai salah satu organisasi "onderbow" PKI. Di samping itu, buruh dianggap sebagai kelompok kelas yang dapat dieksploitisir oleh majikan sebagai budak (dieksploitasi sebagai perbudakan) dengan tidak mengindahkan hak asasi manusia (HAM). Bahkan sampai saat ini, buruh masih dianggap sebagai kelompok yang selalu berusaha menghancurkan "majikan/pengusaha" dalam memperjuangkan hakhaknya.

Pemikiran yang cukup netral terhadap istilah "buruh" apabila kata "buruh" diganti dengan kata "pekerja" sekalipun masih terdapat istilah lainnya seperti "pegawai" atau "karyawan". Istilah pegawai telah melekat dimiliki oleh seseorang yang bekerja di instansi Pemerintah (sebut PNS), sedangkan "karyawan" dapat dimaknai sebagai orang yang melakukan karya atau berkarya. Istilah karyawan lebih bersifat umum, sehingga masyarakat mengenalnya dengan sebutan karyawan buruh, karyawan pengusaha, karyawan ABRI, dsb.

Secara empirik, istilah "pekerja" semestinya lebih luas, yaitu orang yang melakukan pekerjaan, baik dalam hubungan kerja maupun di luar kerja. Fakta menunjukkan bahwa istilah "buruh" terasa kurang proporsional pada zaman penjajahan, yaitu orang yang melakukan pekerjaan "kasar", misalnya kuli angkut barang, tukang batu, montir mobil, dsb. Kelompok buruh ini dikenal dengan sebutan pekerja yang kerah bajunya berwarna biru-gelap (blue collar), sebaliknya, untuk kelompok kerja perkantoran (bidang administrasi) yang bekerja di belakang meja, dikenal dengan sebutan "white collar". Menurut hemat penulis, sudah cukup tepat pergantian istilah "buruh" diganti "pekerja" akan menimbulkan kesan secara psikologis yang lebih netral memanusiakan manusia.

Hal ini sejalan dengan pedoman pelaksanaan Hubungan Industrial Pancasila, yang mencakup: 1) Pengusaha, istilah "pengusaha" digunakan sebagai pengganti istilah "majikan". Majikan pada umumnya dikaitkan dengan kelompok "buruh". Istilah "pengusaha" dirasa lebih mencerminkan kedudukan dalam hubungan industrial Pancasila. Secara definitif, pengusaha adalah orang yang memiliki otoritas mempekerjakan pekerja dengan memberi imbalan upah kerja pada pekerjanya; 2) Serikat pekerja (labor union), pada hakikatnya antara pekerja dan pengusaha bukanlah dua kekuatan yang memiliki perbedan kepentingan, sehingga saling berusaha untuk memenangkan kepentingannya dengan kekuatan tertentu. Namun, justru keduanya saling membutuhkan dan bekerja sama untuk dapat mencapai tujuan yaitu kesejahteraan bersama atas dasar kemitraan. Salah satu perwujudan upaya tersebut adalah mendirikan suatu organisasi pekerja yang diberi nama "Serikat Pekerja". Serikat Pekerja sekaligus sebagai pengganti "Serikat Buruh" dan hal ini sesuai dengan UUD 1945 (Penjelasan Pasal 2) yang menyatakan bahwa "yang disebut golongan-golongan ialah badan-badan seperti koperasi, serikat pekerja dan lain-lain badan kolektif".

Hubungan Industrial Pancasila seharusnya disosialisasikan kepada para anggota "Serikat Pekerja" secara bertahap dan berkesinambungan. Hal ini perlu mendapat perhatian khususnya dari Pemerintah dan serikat pekerja maupun pengusaha karena hal ini dapat menciptakan suasana kerja yang saling menguntungkan yaitu dapat menumbuh kembangkan suasana kekeluargaan, kegotong-royongan, dan musyawarah untuk mufakat dalam aktivitas dan perolehan hakhaknya di perusahaan. Serikat Pekerja merupa-kan serikat atau asosiasi para pekerja untuk jangka waktu yang cukup lama dan berlangsung secara terusmenerus dibentuk dan diselenggarakan dengan tujuan memajukan/mengembangkan kerja sama dan tanggung jawab bersama, baik antara para pekerja, maupun antara pekerja dengan pengusaha. 


\section{Teori Hubungan Industrial}

Ada lima teori yang terkait dengan serikat buruh. Pertama, Teori Kemakmuran Umum, teori ini cenderung mengarah pada pemahaman bahwa apa yang baik bagi Serikat Pekerja baik pula untuk kepentingan bangsa. Upah tenaga kerja yang tinggi merupakan sumber tenaga beli yang mendorong dan memperkuat pertumbuhan ekonomi. Hal ini berakibat pada setiap kenaikan upah mendorong ke arah ekspansi dan pertumbuhan. Perlindungan Serikat Pekerja yang diberikan kepada para anggotanya terhadap tindakan sewenang-wenang para majikan/ pengusaha, diidentifikasikan dengan kemajuan ekonomi. Begitu pula tuntutan jaminan sosial dan kesehatan oleh serikat-serikat pekerja, dipandang sebagai suatu tuntutan yang akan memberi manfaat bagi mereka yang berada di luar Serikat Pekerja. Kedua, Teori Labor Marketing, teori ini cenderung mengarah pada pernyataan bahwa pada umumnya kondisi di tempat pekerja/buruh bekerja ditentukan oleh kekuatan dan pengaruh buruh di pasar dengan tenaga kerja. Serikat Pekerja mengganggap dirinya sebagai "economist agent" di bursa tenaga kerja. Manakala persediaan tenaga kerja lebih besar dari permintaan (demand) maka harga tenaga kerja akan murah, begitu juga sebaliknya. Ketiga, Teori Produktivitas, dalam hal ini, produktivitas kerja sangat menentukan besar kecilnya upah pekerja/buruh di suatu perusahaan. Keempat, Teori Bargaining, di mana tingkat upah pekerja/buruh di tingkat pasar tenaga kerja sangat dipengaruhi oleh kekuatan ekonomi yang berlawanan dari pekerja dan majikan. Apabila buruh meningkatkan ekonominya dengan cara bertindak bersamasama melalui serikat pekerja sebagai bargaining agent maka mereka dapat meningkatkan upah mereka. Kelima, Oposisi Loyal terhadap manajemen, Serikat Pekerja berpendapat bahwa fungsi manajemen adalah mengelola, sedangkan Serikat Pekerja mempunyai tanggung jawab pengawas-an/ pengendalian atas kualitas manajemen. Dengan tanggung jawab ini, manajemen dipaksa untuk selalu berusaha bekerja sebaik mungkin terutama bidang pengunaan tenaga kerja. Namun, teori ini tidak mensyaratkan Serikat Pekerja sebagai manajer, akan tetapi justru menganjurkan Serikat Pekerja menolak tanggung jawab atas manajemen (Anonim, tanpa tahun, Teori Hubungan Industrial, diunduh pada 27 Januari, 2009).

\section{Serikat Pekerja/Serikat Buruh}

Secara yuridis formal, batasan pekerja/buruh secara jelas diungkapkan dalam Pasal 1 angka 2 UU Nomor 13/2003 tentang ketenagakerjaan, yaitu bahwa "Pekerja/buruh adalah setiap orang yang bekerja dengan menerima upah atau imbalan dalama bentuk lain". Selanjutnya, batasan Serikat Pekerja/Serikat Buruh sebagaimana dimaksud dalam Pasal 1 angka 1 UU Nomor 21/2000 adalah bahwa "Serikat Pekerja/Buruh adalah organisasi yang dibentuk dari, oleh, dan untuk pekerja/buruh baik di perusahaan maupun di luar perusahaan, yang bersifat bebas, terbuka, mandiri, demokratis, dan bertanggung jawab guna memperjuangkan, membela serta melindungi hak dan kepentingan pekerja serta meningkatkan kesejahteraan pekerja/buruh dan keluarganya". Atas dasar batasan itu, maka tertutup kemungkinan seseorang yang bukan pekerja/buruh dapat menjadi anggota atau apalagi sebagai pemimpin Serikat Pekerja/Serikat Buruh dimaksud.

Untuk menyalurkan partisipasi pekerja/buruh dalam dunia usaha dan duia industri, dapat dibentuk Serikat Pekerja/Serikat Buruh sebagai wahana untuk menyampaikan berbagai aspirasi dalam mewujudkan partisipasi industri melalui organisasi/perusahaan. Pembentukan Serikat Pekerja atau asosiasi para pekerja dapat direncanakan jangka waktu yang cukup lama dan berlangsung secara terus-menerus dibentuk dan diselenggarakan dengan tujuan memajukan/ mengembangkan kerjasama dan tanggung jawab bersama, baik antara para pekerja, maupun antara pekerja dengan pengusaha.

Selanjutnya, Serikat Pekerja/Serikat Buruh (SP/SB) dapat dibentuk di satu atau lebih perusahaan dan dapat digabung menjadi suatu Federasi. Hal ini sejalan dengan UU Nomor 21/2000 yang menyebutkan bahwa tujuan pendirian SP/SB, federasi dan konfederasi SP/SB adalah untuk memberikan perlindungan, pembelaan hak dan kepentingan, serta meningkatkan kesejah-teraan yang layak bagi pekerja/buruh dan keluarganya (Pasal 4).

Hak berserikat atau berorganisasi dipandang sebagai suatu kebutuhan mutlak yang harus 
dipenuhi sebagai sarana memperjuangkan terpenuhinya hak-hak pekerja/buruh seperti hak atas upah, hak pekerja/buruh perempuan atas fungsi reproduksi dan hak atas kesehatan dan keselamatan kerja. Esensi pembentukan serikat pekerja/serikat buruh telah ditegaskan dalam UU Nomor 21/2000 tentang Serikat Pekerja/Serikat Buruh. Secara eksplisit konsideran UU tersebut menyebutkan bahwa serikat/pekerja/serikat buruh merupakan sarana untuk memperjuangkan, melindungi, dan membela kepentingan dan kesejahteraan pekerja/buruh beserta keluarganya, serta mewujudkan hubungan industrial yang harmonis, dinamis, dan berkeadilan.

Selanjutnya, dalam ketentuan Pasal 110 ayat (1), (2), dan (3) menyebutkan bahwa peraturan perusahaan disusun dengan memperhatikan saran dan pertimbangan dari wakil pekerja/buruh. Dalam hal ini, di perusahaan-perusahaan telah terbentuk serikat-serikat pekerja/serikat-serikat buruh otomatis notabene mewakili sebagai pengurus perserikatan. Dalam menajalankan sebagai fungsinya, serikat pekerja/serikat buruh dituntut untuk berperan aktif manakala terjadi perselisihan antara buruh dan pengusaha, dengan tetap berdiri di atas kepentingan pekerja/ buruh. Namun demikian, sebagaimana dimaksud dalam Pasal 151 ayat (1) dan ayat (2) UU Nomor $13 / 2003$ pada intinya diharapkan agar pengusaha tidak melakukan pemutusan hubungan kerja (PHK) manakala terjadi perselisihan yang berkepanjangan (Anonim,tanpa tahun, Gabungan Federasi Serikat Pekerja/Serikat Buruh, 20 Februari 2008).

\section{Organisasi Buruh Internasional (International Labour Organization)}

International Labour Organization (ILO) didirikan pada tahun 1919, setahun setelah Perang Dunia I berakhir. Organisasi ILO bertujuan untuk memperbaiki kondisi para pekerja sebagai upaya mewujudkan keadilan sosial di seluruh dunia. Untuk mencapai tujuan tersebut, ILO mengadopsi struktur tripartit yang khas, yaitu terdiri atas perwakilan pemerintah, pekerja, dan pengusaha. Ketiga unsur tersebut secara bersama-sama bertugas merencanakan strategi dan cara yang terbaik untk mencapai tujuan ILO (Anonim, tanpa tahun, Organisasi Buruh Internacional (ILO) Biro Pendidikan Pekerja (Actrav): ILO dan Pekerja)
Kebijakan ILO dalam kemitraan diberikan dalam bentuk bantuan khusus yang diberikan kepada serikat pekerja/buruh dalam kerangka kemitraan aktif. Prioritas dan kemitraan aktif adalah pemberian bantuan dan advokasi teknis dalam penerapan standar perburuhan internasional, khusunya konvensi dasar ILO tentang pokok-pokok Hak Asasi Manusia (HAM). Tim multidisipliner ini terdiri atas pakar-pakar kegiatan pekerja/buruh. Tim ini bertanggung jawab mendorong partisipasi serikat pekerja/serikat buruh dalam kegiatan-kegiatan ILO dan memastikan bahwa program dan proyek yang dijalankan sesuai dengan kebutuhan serikat/pekerja secara efektif.

Biro pendidikan Pekerja (ACTRAV) merupakan suatu unit khusus di $I L O$, berfungsi untuk memelihara jaringan/hubungan antarserikat pekerja/buruh di negara-negara anggota, menempatkan sumber daya yang dimiliki $I L O$ untuk kepentingan serikat pekerja/buruh dan untuk menjaga agar ILO tetap berhubungan dekat dengan agenda, prioritas, kepentingan, dan pandangan dari serikat pekerja/buruh (anonim, tanpa tahun).

Skala prioritas ACTRAV mempromosikan: a) pengembangan dan penguasaan organiasasi serikat pekerja/buruh yang representatif, independen, dan demokratis, b) penguatan kapasitas organisasi serikat pekerja/buruh untuk terlibat dalam pengambilan keputusan di level legal, sosial, dan ekonomi, c) forum koordinasi bagi semua kegiatan, program, dan proyek ILO agar sesuai dengan kebutuhan serikat pekerja/buruh, dan d) partisipasi aktif pekerja/buruh dalam kegiatan-kegiatan ILO.

Di samping itu, ACTRAV juga menyediakan bantuan teknis untuk serikat pekerja/buruh melalui program konsultasi/advisory dan pelatihan, seperti seminar dan kursus-kursus dalam bidang: 1 ) Standar legislasi dan standar perburuhan internasional; 2) Hubungan internasional dan perundingan bersama (collective bargaining); 3) Kebijakan ketenagakerjaan; 4) Jaminan sosial; 5) Keselamatan dan kesehatan kerja dan lingkungan kerja; 6) Persamaan kesempatan dan gerakan anti diskriminasi; 7) Metode pelatihan dan belajar jarak jauh yang modern; dan 8) Manajemen dan administrasi serikat pekerja/buruh.

Dengan demikian, dapat dikatakan bahwa ILO memberikan kesempatan kepada negara-negara 
anggotanya untuk bersama-sama berpartisipasi dalam mewujudkan program dan kegiatan ILO serta memberi kesempatan kepada serikat pekerja/buruh untuk mendorong anggotanya mengkuti berbagai kesempatan mengiuti program-program ILO yang telah ditetapkan.

\section{Asosiasi Pengusaha Indonesia (APINDO)}

Asosiasi Pengusaha Indonesia merupakan organisasi para pengusaha Indonesia atau disingkat APINDO. Organisasi ini merupakan wadah kesatuan para pengusaha yang ikut serta untuk mewujudkan kesejahteraan sosial dalam usahanya melalui kerjasama yang terpadu dan serasi antara Pemrintah, pengusaha dan pekerja. APINDO berbentuk badan hukum, bersifat demokratis, dengan lingkup kegiatan sosialekonomi, khususnya di bidang hubungan industrial dan ketenagakerjaan (Blog at WordPress.com).

Selanjutnya, beberapa hal terkait dengan tujuan organisasi sesuai dengan Anggaran Dasar (AD) Pasal 7, menyebutkan antara lain bahwa: 1) Menciptakan dan memelihara keseimbangan, ketenangan, dan kegairahan kerja dalam lapangan hubungan perburuhan dan ketenagakerjaan, 2) Mengusahakan peningkatan produktivitas kerja sebagai peran serta akktif untuk mewujudkan pembangunan nasional menuju kesejahteraan sosial, spiritual, dan material, serta 3) Menciptakan adanya kesatuan pendapat dalam melaksanakan kebijaksanaan perburuhan dari para pengusaha yang disesuaikan dengan kebijaksanaan Pemerintah.

Lebih lanjut, dalam Anggaran Rumah Tangga (ART) Pasal 8 lebih rinci memuat hal-hal yang antara lain berkaitan dengan kerjasama, baik internal organisasi (pekerja dan pengusaha), pemerintah, maupun organisasi swasta, melakukan pendidikan dan pelatihan bagi para anggotanya, menyelesaikan permasalahan, pembentukan badanbadan di daerah, memberikan saraan kepada pemerintah, pembinaan anggota, mebentuk forum diskusi, dsb. Hal tersebut mengindikasikan bahwa APINDO mendorong dan memberikan kesempatan kepada para pekerja dan pengusaha untuk berpartisipasi secara aktif dalam hubungan industrial Pancasila sesuai dengan bidang keahliannya masingmasing.

\section{Gerakan Pekerja/Buruh}

Proses industrialisasi merupakan wahana tumbuh dan berkembangnya organisasi buruh. Organisasi ini berusaha untuk mempengaruhi dan memperjuangkan kondisi para pekerja, kebijakan, dan praktik manajemen serta kebijakan Pemerintah mengenai kondisi, persyaratan kerja, dan hubungan kerja. Di Amerika dan Eropa misalnya, para pengusaha membentuk organisaasi untuk mengimbangi dan membatasi pengaruh organisasi buruh (http://survey07.ituc-csi.0rg/getcountry. pnp?IDLang=EN\&IDCountry $=$ IDN\&ID Supp $=\ldots 18 /$ 10/2008).

Istilah gerakan buruh secara umum meliputi berbagai macam asosiasi yang timbul dalam kondisi ekonomi industri. Gerakan buruh merupakan seluruh aktivitas para penerima upah (buruh) untuk memperbaiki kondisi kerja mereka (The Encyclopedia of Social Science). Serikat buruh atau serikat pekerja merupakan asosiasi para penerima upah (buruh) yang bersifat sukarela dan berkesinambungan dan memiliki tujuan jangka panjang untuk melindiungi para anggotanya dalam hubungan kerja maupun meningkatkan taraf hidup mereka. Lebih lanjut, sebagaimana dikatakan oleh tokoh perburuhan seperti Kerr, Dunlop, Herbison, dan Myers menyimpulkan bahwa industrialisasi menciptakan berbagai macam organisasi kaum buruh, sekalipun beda fungsi, struktur kepemimpinan, dan ideologi (http://www. (ppi) (ppiindia). Kondisi tersebut menye-babkan ketidak seimbangan para pekerja, sehingga tujuan gerakan buruh berubah-ubah dari waktu ke waktu.

Keberadaan Serikat Pekerja/Serikat Buruh mempunyai pengaruh yang sangat signifikan dalam dunia ketenagakerjaan di Indonesia. Hal ini terbukti dengan berbagai kebijakan Peme-rintah, selalu direspon dengan beragam tanggapan/reaksi dari serikat-serikat pekerja/buruh (http://www. (ppi) (ppiindia). Namun, yang cukup diwaspadai adalah pada akhir-akhir ini gerakan Serikat Pekerja seringkali terjebak dalam suasana kemelut muatan politik sehingga meninggalkan nilai-nilai dasar perjuangan organisasi/asosiasi Serikat Pekerja itu sendiri. Hal ini layak diduga bahwa telah terjadi fenomena semakin banyaknya pemimpin serikat pekerja yang pada kenyataannya bukan berasal dari pekerja/buruh itu sendiri. Hal itu dirasa jelas kurang menguntungkan bagi para pekerja karena mereka kurang menghayati 
hak-hak pekerja, perlakuan yang kurang menguntungkan bagi pekerja, dan nasib pekerja di Indonesia pada umumnya. Sementara itu, manakala terjadi perundingan "tripartrit" yang membahas isu-isu perburuhan/ketenagakerjaan diwakili oleh orangorang yang bukan dari unsur pekerja, sehingga jarang sekali hasil perundingan tersebut berpihak kepada kaum buruh/pekerja.

Permasalahan perburuan di Indonesia merupakan masalah yang akut yang dibiarkan sampai menumpuk tanpa ada upaya untuk menuntaskan pemecahannya. Ketenagakerjaan di Indonesia belum mendapatkan perhatian yang proporsional oleh Pemerintah, terutama dari aspek pemberian jaminan kebebasan berserikat dalam menyatakan pendapat bagi pekerja, kebijakan pengupahan, dan jaminan sosial pekerja yang kurang sesuai dengan kelayakan kebutuhan hidup minimal (KHM) dan lembaga peradilan perburuhan (http://www.hukumonline. com/detail. asp?id=18838\&cl=Berita). Sebaliknya, di kalangan masyarakat dan serikat pekerja/ serikat buruh belum tumbuh kesadaran yang berkembang terhadap budaya berorganisasi (labor union) yang sehat dan sportif serta dewasa dan bebas dari muatan politik, akibatnya pendewasan kepribadian kurang, sehingga muncul radikalisme tuntutan yang berlebihan dan sering tanpa membawa hasil.

Oleh karena itu, dalam mendorong para pekerja/buruh berpartisipasi aktif dan berkontribusi pada sasaran kegiatan industri diharapkan pengurus seerikat pekerja/serikat buruh mau dan mampu melakukan advokasi dan memberikan motivasi kepada setiap anggotanya agar manajemen kinerja perusahaan selalu meningkat dari waktu ke waktu. Untuk itu, diperlukan upaya konkrit dalam bentuk pembinaan dan bimbingan teknis yang dapat menciptakan saling pengertian (mutual understanding) dan saling menguntung-kan (mutual benefit) bagi kedua belah pihak (pekerja dan pengusaha). Dengan demikian, diharapkan dapat tercipta iklim kerja yang aman, nyaman, dan menyenangkan serta dalam koridor yang kondusif sehingga manajemen kinerja dapat meningkat.

Suatu hal yang perlu digaris bawahi ádalah bahwa Undang-Undang menjamin atau Peme-rintah memberikan perlindungan kepada para aktivis serikat pekerja/serikat buruh untuk tetap melaksanakan aktivitasnya yang positif sepanjang tidak ber- tentangan dengan UU. Hal ini dengan tegas dijamin oleh: 1) UU Nomor 13/2003 tentang Ketenagakerjaan Pasal 153 ayat (1) huruf g; 2) UU Serikat Pekerja/Serikat Buruh Nomor 21 /2000, Pasal 28 huruf a; dan 3) UU Serikat Pekerja/Serikat Buruh Nomor $21 / 2000$ Pasal 43 ayat (1).

\section{Peran Negara dalam Hubungan Perburuhan di Indonesia}

Dalam kaitannya dengan hubungan industrial, Pemerintah Indonesia berperan sebagai pelindung pekerja/buruh, antar lain dalam bentuk penyusunan berbagai peraturan perundang-undangan dan peraturan pemerintah maupun keputusan menteri sebagai pelengkap penyertanya. Selain itu, sebagai fasilitator dalam penyelesaian persengketaan perkerja/buruh dengan majikan/pengusaha dalam mencari titik temu antara kedua pihak dalam mendapatkan hak-hak sebagaimana diatur dalam undang-undang.

Secara empirik, sampai saat ini masih sering terjadi konflik kepentingan antara pekerja/buruh dan majikan/pengusaha, baik dimuat/disiarkan dalam media cetak maupun media elektronik. Hubungan pekerja/buruh dan majikan/pengusaha harus difahami bahwa posisi pekerja/buruh sebagai subordinatif terhadap majikan/pengusaha. Hal ini sering dikemas dalam jargon politik adanya ketidakseimbangan kekuasaan ekonomi yang pada akhirnya menimbulkan ketidakseimbagan kekuasaan politik bagi pekerja/buruh dengan majikannya.

Beberapa kasus perburuhan di Indonesia adakalanya cenderung memicu kerusuhan yang mengarah pada perbuatan anarki. Hal ini merupakan tugas Pemerintah untuk mencari akar permasalahan dan mencari upaya pemecahannya dengan prinsip win-win solution dengan mengacu pada peraturan perundang-undangan. Dapat diasumsikan bahwa perselisihan itu akan terjadi titik temu, manakala masing-masing pihak mengedepankan "kejujuran". Faktor "kejuruan" diyakini sebagai faktor yang mahal dalam upaya pemecahan berbagai permasalahan atau konflik antara pekerja/buruh dengan majikan/pengusaha. Di samping itu, faktor "kedewasaan" bagi pekerja maupun majikan dalam berorganisasi/berserikat juga akan mewarnai upaya penye-lesaian setiap pemasalahan yang terjadi.

Penyediaan lapangan kerja menjadi kebutuhan yang mendesak. Dalam situasi politik yang belum 
stabil, apa yang ditawarkan Pemerintah selain upah pekerja murah? Namun, manakala kebijakan tersebut diterapkan, maka Pemerintah akan terjebak dengan paradigma lama dalam politik perburuhannya. Dalam hal ini semestinya Pemerintah tetap berpijak pada dasar perhitungan UMR sebesar 80 persen dari kebutuhan hidup minimal (KHM). Pemerintah juga seharusnya memberikan pengertian dan mengajak para pekerja/buruh untuk menerima ketetapan pengupahan yang telah diperbaiki. Upaya tersebut seharusnya diimbangi dengan jaminan resmi bagi para pekerja/buruh untuk menyalurkan aspirasi/ pendapatnya melalui saluran undang-undang dan Pemerintah mengupayakan membentuk lembaga peradilan perburuhan yang independen.

Konflik kepentingan antara pekerja/buruh dan majikan/pengusaha akan terus berkelanjut-an, manakala pihak Pemerintah belum mampu memfasilitasi dengan peraturan perundangundangan dan meningkatkan keterampilan (kompetensi) calon tenaga kerja melalui diklat dengan menyesuaikan standar kompetensi yang dipersyaratkan oleh dunia usaha dan dunia industri (DUDI). Dengan kata lain, upaya pembekalan calon tenaga kerja melalui "diklat" diharapkan dapat menciptakan sistem pendidikan dan pelatihan melalui filosofi keterkaitan dan kesepadanan (link and match) dengan pendekatan "dual system" atau sistem ganda. Pendekatan ini dimaksudkan untuk mendekatkan antara pendidikan dengan dunia usaha/dunia industri. Hal penting dan perlu segera diupayakan oleh Kemdiknas (pendidikan) dan Kemnakertrans (pelatihan) adanya pembatasan yang konkrit apa yang menjadi tanggung jawab masing-masing Kementerian tersebut. Sepanjang tidak ada ketegasan yang secara resmi dari kedua Kementerian tersebut maka masalah kesiapan calon tenaga kerja akan tetap "di persimpangan jalan" dan tidak pernah akan ada penyelesaian masalah yang mendasar.

Hubungan pekerja/buruh dengan industri perlu dibingkai dalam aturan main dalam peraturan perundang-undangan. Hubungan ini diharapkan dapat saling menciptakan suasana "saling pengertian dan saling menguntungkan" (mutual simbiosis dan mutual benefit) sebagai bentuk suatu kemitraan. Sebagai konsekuensi hubungan subordinatif maka perlu mempertimbangkan faktor "keseimbangan keadilan" secara proporsional terhadap setiap perlakuan, sekalipun konsep "adil" relatif bagi masing-masing pihak dalam pemenuhan kebutuhannya.

Perlindungan terhadap yang lemah secara empirik telah dituangkan dalam UUD 1945 dalam wujud keadilan sosial berdasarkan atas kekeluargaan. Selanjutnya, sikap Negara terhadap hubungan pekerja/buruh dan majikan serta tanggung jawab yang harus diembannya dapat dicermati dari sikap pembentuk negara (founding father and mother). Pada rapat Panitia Persiapan Kemerdekaan Indonesia (PPKI) tanggal 19 Agustus 1945 telah diupayakan pembentukan Kementerian Kesejahteraan yang membawahi perburuhan, perawatan fakirmiskin, anak yatim-piatu, dan zakat fitrah (A.S Finawati, dalam www.pemantauanperadilan.com). Pada akhirnya, Kementerian tersebut diputuskan sebagai Departemen Sosial yang membidangi urusan perburuhan, fakir miskin, dsb.

\section{Peraturan Perundang-undangan Politik Hukum Perburuhan Era Orde Lama dan Orde Baru}

Pada zaman orde lama, UU tentang Perburuhan mengatur lebih lanjut perlindungan sebagai-mana termaktub dalam UUD 1945. Terdapat delapan Peraturan perundang-undangan yang mengatur perburuhan, yaitu: 1) UU Nomor 1/1951 tentang Pernyataan Berlakunya UU Nomor 12/1948 tentang Kerja; 2) UU Nomor 2/1951 tentang Berlakunya UU Nomor 33/1947 tentang Kecelakaan Kerja; 3) UU Nomor 3 /1951 tentang Pernyataan Berlakunya UU Nomor 23/1948 tentang Pengawasan Perburuhan; 4) UU Nomor 21/1954 tentang Perjanjian Perburuhan antara Serikat Buruh dan Majikan; 5) UU Nomor 18/1956 tentang Persetujuan Konvensi ILO No. 98 mengenai berlakunya Dasardasar dari hak untuk berorganisasi dan untuk berunding bersama; 6) UU Nomor 22/1957 tentang Penyelesaian Perselisihan Perburuhan; 7) UU Nomor 3/1958 tentang Penempatan Tenaga Asing; dan 8) UU Nomor 12/1964 tentang Pemutusan Hubungan Kerja di Perusahaan Swasta. Berikut ini produk hukum terkait dengan perburuhan di Indonesia (Tabel 1).

Selain itu, masih terdapat 13 surat keputusan menteri dengan rincian 8 keputusan bersifat campur tangan untuk menghegemoni pekerja/buruh, dan 5 keputusan berkaitan dengan pembatasan, pelarangan, dan penekanan pekerja/buruh. Salah 
Tabel 1. UU Terkait dengan Perlindungan Perburuhan di Indonesia

\begin{tabular}{|c|c|c|}
\hline No & Undang-Undang & Konsep Perlindungan \\
\hline 1 & $\begin{array}{l}\text { UU Nomor } 1, \text { Tahun } \\
1951 \text { tentang Pernyata- } \\
\text { an Berlakunyar UU } \\
\text { No.12/1948 tentang } \\
\text { Kerja }\end{array}$ & $\begin{array}{l}\text { 1. Larangan memperkerjakan anak } \\
\text { 2. Pembatasan waktu kerja } 7 \text { jam sehari, } 40 \text { jam seminggu } \\
\text { 3. Waktuistirahan bagi buruh } \\
\text { 4. Larangan memperkerjakan buruh pada hari libur } \\
\text { 5. Hak cuti haid } \\
\text { 6. Hak cuti melahirkan/keguguran } \\
\text { 7. Saksi pidana untuk pelanggaran ketentuan dalam UU ini }\end{array}$ \\
\hline 2 & $\begin{array}{l}\text { UU Nomor 2, } \text { Tahun } \\
1951 \text { tentang Berlaku- } \\
\text { nya UU Nomor 33/1947 } \\
\text { tentang Kecelakaan } \\
\text { Kerja }\end{array}$ & $\begin{array}{l}\text { 1. Jaminan atas kecelakaan kerja } \\
\text { 2. Hak pegawai pengawas untuk menjamin pelaksanaan } \\
\text { jaminan kecelakaan kerja } \\
\text { 3. Sanksi pidana untuk pelanggaran ketentuan dalam UU } \\
\text { ini }\end{array}$ \\
\hline 3 & $\begin{array}{l}\text { UU Nomor 3, Tahun } \\
1951 \text { tentanag Pernya- } \\
\text { taan Berlakunya UU } \\
\text { Nomor 23/1948 ten- } \\
\text { tang Pengawasan Per- } \\
\text { buruhan }\end{array}$ & $\begin{array}{l}\text { 1. Kewajiban Negara untuk melakukan pengawasan } \\
\text { terhadap pelaksanaan UU ini dan Peraturan Perburuhan } \\
\text { 2. Hak pegawai pengawas memasuki dan memeriksa } \\
\text { tempat usaha } \\
\text { 3. Kewajiban majikan untuk memberikan keterangan lisan } \\
\text { dan tertulis kepada pegawai pengawas } \\
\text { 4. Saksi pidana untuk pelanggaran ketentuan dalam UU ini }\end{array}$ \\
\hline 4 & $\begin{array}{l}\text { UU Nomor 21, Tahun } \\
1954 \text { tentang Perjanji- } \\
\text { an Perburuhan antara } \\
\text { Serikat Buruh dan } \\
\text { Majikan }\end{array}$ & $\begin{array}{l}\text { 1. Jaminan perjanjian perburuhan tetap berlaku walau } \\
\text { serikat buruh kehilangan anggotanya } \\
\text { 2. Jaminan perjanjian perburuhan tetap berlaku walau } \\
\text { serikat buruh bubar } \\
\text { 3. Aturan tentang perjanjian perburuhan lebih tinggi } \\
\text { keduduk-annya dibandingkan dengan perjanjian kerja } \\
\text { antara seorang buruh dengan majikan } \\
\text { 4. Pembatasan untuk majikan tidak boleh membuat } \\
\text { perjanjian perburuhan dengan serikat buruh lain yang } \\
\text { lebih rendah syarat kerjanya dengan perjanjian } \\
\text { perburuhan yang sudah pernah dibuatnya }\end{array}$ \\
\hline 5 & $\begin{array}{l}\text { UU Nomor 18, Tahun } \\
1956 \text { tentang Persetu- } \\
\text { juan Konvensi ILO No. } \\
98 \text { mengenai berlaku- } \\
\text { nya Dasar-dasar dari } \\
\text { hak untuk berorgani- } \\
\text { sasi dan untuk berun- } \\
\text { ding bersama }\end{array}$ & $\begin{array}{l}\text { Perlindungan hak berserikat: } \\
\text { (1) larangan diskriminasi karena menjadi anggota serikat } \\
\text { buruh dan melakukan aktivitas sebagai anggota serikat } \\
\text { buruh, dan } \\
\text { (2) larangan mendominasi atau melakukan kontrol terhadap } \\
\text { serikat buruh }\end{array}$ \\
\hline 6 & $\begin{array}{l}\text { UU Nomor 22, Tahun } \\
1957 \text { tentang Penyele- } \\
\text { saian Perselisihan Per- } \\
\text { buruhan }\end{array}$ & $\begin{array}{l}\text { 1. Definisi mogok yang cukup luas: } \\
\text { (1) tindakan kolektif menghentikan memperlambat } \\
\text { jalannya pekerjaan } \\
\text { (2) akibat perselisihan perburuhan } \\
\text { (3) maksud untuk menekan majikan atau membantu } \\
\text { golongan buruh lain menekan majikan } \\
\text { (4) kgar menerima hubungan kerja, syarat-syarat } \\
\text { kerja dan/atau keadaan perburuhan } \\
\text { 2. Pembentukan P4D/P yang terdiri atas } 3 \text { pihak secara } \\
\text { berimbang jumlahnya: pemerintah, wakil buruh, dan } \\
\text { wakil pengusaha } \\
\text { 3. Ketentuan purtusan P4D/P bersifat mengikat dan dapat } \\
\text { dimintakan eksekusi ke pengadilan negeri } \\
\text { 4. Arbitase secara voluntary } \\
\text { 5. Sanksi untuk pelanggaran ketentuan dalam UU ini }\end{array}$ \\
\hline 7 & $\begin{array}{l}\text { UU Nomor 3, Tahun } \\
1958 \text { tentang Penem- } \\
\text { patan Tenaga Asing }\end{array}$ & $\begin{array}{l}\text { Pengaturan dan pembatasan memperkerjakan tenaga kerja } \\
\text { asing berarti perlindungan terhadap jaminan pekerjaan bagi } \\
\text { warga asing }\end{array}$ \\
\hline 8 & $\begin{array}{l}\text { UU Nomor } 12, \text { Tahun } \\
1964 \text { tentang Pemutus- } \\
\text { an Hubungan Kerja di }\end{array}$ & $\begin{array}{l}\text { 1. Ketentuan pengusaha harus mengusahakan tidak terjadi } \\
\text { PHK } \\
\text { 2. Larangan PHK karena sakit selama tidak melebihi } 12\end{array}$ \\
\hline
\end{tabular}

Sumber: Anonim, tanpa tahun, Ringkasan Eksekutif Hasil Kajian Akademis Terhadap UU No.13 Tahun 2003 Tentang Ketenagakerjaan. 
satu dari 8 Kepmen adalah Kepmen Nomor 648/Men/ 1985 tentang Pelak-sanaan Hubungan Industrial Pancasila yang pada hakikatnya melemahkan gerakan buruh maupun serikat buruh. Dengan menentang konflik, dalam praktiknya menolak hak pekerja/buruh untuk melakukan aksi mogok. Hal ini dianggap tidak selaras dengan prinsip kekeluargaan yang melandasiPancasila(http://survey07.ituccsi. 0rg/getcountry.pnp?IDLang=EN\&IDCountry $=I D N \&$ IDSupp $=\ldots 18 / 10 / 2008$ ).

Keputusan yang secara tegas membatasi mogok kerja tertuang dalam Kepmen Nomor: 4/ Men/1986 yang menekan hak mogok kerja dan pembentukan serikat pekerja/buruh (Anonim, tanpa tahun, Ringkasan Eksekutif Hasil Kajian Akademis Terhadap UU No.13 Tahun 2003 Tentang Ketenagakerjaan). Di samping itu, Keputusan Menteri Nomor 342/Men/1986 tentang penentuan aparat keamanan (Korem, Kodim, Kores) dibolehkan ikut campur menangani perselisihan perburuhan. Padahal, mogok kerja oleh serikat pekerja/buruh dijadikan sebagai wahana untuk mempromosikan dan membela kepentingan ekonomi dan sosial mereka secara legal.

\section{Aspek Legal Formal}

Politik perburuhan di Indonesia masih belum tertata dengan acuan yang memberikan rambu-rambu dalam berorganiasasi secara profesional. Pada waktu B.J Habibie sebagai Presiden RI, telah mengeluarkan UU tentang Ketenagakerjaan Nomor 25/1997 yang saat ini telah diperbaharui melalui UU Nomor 13/ 2003. Namun, UU Nomor $21 / 2000$ mengatur khusus tentang Serikat Pekerja/Serikat Buruh yang dalam praktik implementasinya masih belum berpihak kepada para pekerja/buruh khususnya manakala terjadi perselisihan kepentingan. Hal ini ditunjukkan beberapa kasus seperti di PT Kong Tai Indonesia (KTI) dan beberapa kasus di perusahaan lainnya yang ber-akibat pada diberlakukannya pemutusan hubungan kerja (PHK).

Dari aspek legal formal, sampai saat ini belum ada undang-undang khusus tentang perlindungan pekerja/buruh yang berpihak kepada kepentingan pekerja/buruh. Lebih lanjut, implementasi UU yang ada seperti UU HAM No. 39/1999; UU Keimigrasian; UU RI Tahun 1984 (ratifikasi konvensi Penghapusan Segala Bentuk Diskriminasi terhadap perempuan/CEDAW: Pasal: 2, 6, 9, 11, 12,
14, 15, dan 16); UU RI No.20/1999 (ratifikasi konvensi ILO No. 38 tentang usia minimum yang diperbolehkan bekerja; Ratifikasi 1990 tentang Perlindungan buruh migran dan keluarganya; Keppres No.36/1990 (ratifikasi Konvensi Hak Anak), UU Nomor 21/2000 tentang Serikat Pekerja/Serikat Buruh, dan UU Nomor 13/2003 tentang Ketenagakerjaan, dsb (UU RI Nomor 20/1999). Namun, kenyataannya belum dapat menangani berbagai kasus ketenagakerjaan secara utuh dan tuntas

\section{Hak Ekonomi Pekerja/Buruh}

Hak ekonomi pekerja/buruh dapat diartikan berbagai peraturan-peraturan yang menyangkut kesejahteraan secara langsung bagi para pekerja/ buruh. Beberapa peraturan dimaksud antara lain sebagaimana tercantum pada Tabel 3.

Sepintas aturan-aturan tersebut berisi perlindungan terhadap pekerja/buruh, akan tetapi jika ditelaah lebih mendalam berbagai peraturan tersebut terindikasi mengurangi hak-hak pekerja/ buruh. Sebagai contoh, aturan tentang pekerja lepas, tidak hanya melegitimasi jenis hubungan kerja harian lepas tetapi perlindungan yang ada dalam Permenaker tersebut, yaitu tentang ketentuan jumlah bulan dan hari dalam sebulan untuk pekerja lepas tidak boleh melebihi 3 bulan berturut-turut dan 20 hari kerja dalam setiap bulannya. Hal ini membuka peluang untuk mengekploitasi buruh dan membuatnya tetap pada status pekerja/buruh harian lepas (A.S Finawati, dalam www. pemantauan peradilan. com).

Kondisi yang sedikit berbeda dalam Kepmenaker nomor 150/Men/2000 yaitu apabila dua peraturan menteri tentang pekerja harian lepas dan kontrak membuka peluang penyelundupan hukum maka peraturan tentang pesangon dalam ketentuannya sudah melemahkan dan mengurangi perlindungan terhadap pekerja/buruh yang ada dalam undang-undang. Hal serupa juga terjadi dalam pengaturan tentang upah minimum yang pada kenyataanya justru menjadi aturan upah maksimum. Selain mendasarkan pada kebutuhan fisik minimum/KFM padahal lebih layak dengan kebutuhan hidup minimum/KHM (ditambah lagi pada praktiknya sering tidak sesuai dengan perhitungan KFM). Ketidakjelasan aturan ini menyebabkan pekerja/buruh dengan masa kerja bertahun-tahun juga mendapat upah sebesar upah minimum, sama 
Tabel 3. Peraturan Pemerintah Terkait Hak Ekonomi Pekerja/Buruh

\begin{tabular}{|c|c|c|}
\hline NO & $\begin{array}{c}\text { Peraturan } \\
\text { Menteri/Kebijakan }\end{array}$ & Isi Ketentuan \\
\hline 1 & $\begin{array}{l}\text { PP Nomor } 8 \text { Tahun } 1981 \\
\text { tentang Perlindungan Upah }\end{array}$ & $\begin{array}{l}\text { 1. Perlindungan pembayaran upah } \\
\text { 2. Asas no work no pay } \\
\text { 3. Kadaluwarsa tuntutan yang berkaitan dengan } \\
\text { hubungan kerja selama } 2 \text { tahun }\end{array}$ \\
\hline 2 & $\begin{array}{l}\text { Permenaker Nomor 6/ } \\
\text { Men/1985 }\end{array}$ & Aturan tentang pekerja harian lepas \\
\hline 3 & $\begin{array}{l}\text { Permenaker Nomor 5/ } \\
\text { MEN/1986 yang diganti } \\
\text { dengan Permenaker No- } \\
\text { mor 2/MEN/1993 }\end{array}$ & $\begin{array}{l}\text { Aturan mengenai kesepakatan kerja waktu tertentu } \\
\text { (pekerja kontrak) }\end{array}$ \\
\hline 4 & $\begin{array}{l}\text { Permenaker Nomor 4/ } \\
\text { MEN/1986 yang diganti } \\
\text { dengan Permenaker No- } \\
\text { mor 3/MEN/1996 dan akhir } \\
\text { nya menjadi Pe-menaker } \\
\text { Nomor } 150 / \text { MEN/2000 ten- } \\
\text { tang Penyelesaian PHK dan } \\
\text { Penetapan Pesangon, Uang } \\
\text { Jasa, dan Ganti Kerugian di } \\
\text { Perusahaan Swasta }\end{array}$ & $\begin{array}{l}\text { 1. Ketentuan tentang mangkir bagi buruh } \\
\text { 2. Mereduksi kewajiban untuk menjalankan hak adan } \\
\text { kewajiban buruh-majikan selama proses PHK dan UU } \\
\text { dengan adanya skorsing terhadapekerja/buruh } \\
\text { 3. Aturan PHK karena kesalahan berat (tidak mendapat } \\
\text { pesangon) } \\
\text { 4. Aturan pemberian SP (surat peingatan) bagi } \\
\text { pekerja/buruh }\end{array}$ \\
\hline 5 & $\begin{array}{l}\text { Permenaker Nomor 5/ Men/ } \\
1989 \text { yang diganti dengan } \\
\text { Permenaker No-mor 1/MEN } \\
\text { /1996 dan akhirnya menja } \\
\text { di Permenaker Nomor } \\
\text { 3/MEN / } 1997\end{array}$ & Aturan tentang Upah minimum \\
\hline
\end{tabular}

Sumber: Anonim, tanpa tahun, Ringkasan Eksekutif Hasil Kajian Akademis Terhadap UU No.13 Tahun 2003 Tentang Ketenagakerjaan

dengan buruh yang baru masuk bekerja (Anonim, tanpa tahun, Ringkasan Eksekutif Hasil Kajian Akademis Terhadap UU No.13 Tahun 2003 Tentang Ketenagakerjaan)

\section{Kondisi Tenaga Kerja Saat Ini dan Implementasinya di Lapangan}

Peran Negara atau Pemerintah dalam hubungan dengan industrial di Indonesia, sebenarnya telah cukup banyak produk hukum serta penyertanya. Sebagai salah satu contoh, UU Nomor 25, Tahun 1997 tentang Ketenagakerjaan. Semenjak berlakunya UU tersebut, yang dimaksud dengan pengganti dan kompilasi seluruh aturan perburuhan tidak berhasil untuk diberlakukan dan harus ditunda karena penolakan masyarakat pekerja/buruh terus berlanjut. Akhirnya, Pemerintah menawarkan untuk mengajukan turunan UU tersebut dalam 3 paket, yaitu RUU Perburuhan, RUU Perlindungan Pembinaan Ketenagakerjaan (PPK) dan RUU Penyelesaian Perselisihan Hubungan Industrial (PPHI). Ada tiga produk hukum yang merupakan peran dan tanggung jawab Negara dalam hubungan industrial, namun dalam implementasinya masih terdapat ketimpangan dalam keberpihakan terhadap serikat pekerja/serikat buruh.

Pertama, Undang-Undang Nomor 21/2000 Tentang Serikat Pekerja/Serikat Buruh. Secara formalitas Undang-Undang ini mengakui dan menjamin para pekerja/buruh mendapatkan kebebasan untuk berserikat. Namun, jaminan tersebut direduksi oleh beberapa pasal dalam UU ini. Misalnya, pencatatan serikat pekerja/serikat buruh di tingkat provinsi/kabupaten/kota ke Dinas Nakertrans setempat semestinya berfungsi sebagai administratif. Namun, pada praktiknya pencatatan tersebut sebagai syarat legalisasi sah tidaknya keberadaan serikat pekerja/serikat buruh. Hal ini dijadikan dasar bahwa dengan pencantuman hak-hak serikat pekerja/serikat buruh selalu ditekankan pada status "serikat pekerja/serikat buruh yang telah mencatatkan diri serta mempunyai 
nomor bukti pencatatan berhak...." Hal ini dirasakan oleh serikat pekerja/serikat buruh sebagai pembatasan berserikat bagi yang tidak mencatatkan diri ke Dinas Nakertrans setempat. Lebih parah lagi nomor bukti pencatatan selalu ditanyakan oleh Depnaker dan lembaga penyelesaian perselisihan perburuhan (P4D/P). Dengan kata lain, kebebasan berserikat yang dijamin sebagaimana termaktub dalam UU Nomor 21/2000 dianggap telah dilanggar. Dengan demikian, Negara dianggap tidak mampu mengimplementasikan UU ini terutama dalam hal perlindungan kebebasan berserikat. Sekalipun dalam kenyataannya terdapat klausul tentang ancaman bagi yang melangar akan dikenai hukuman penjara selama 1-5 tahun atau denda sebesar 100-500 juta, namun dalam kenyataannya tidak ada satu pun pelanggaran berserikat dikenai hukuman dan bahkan tidak ada satupun kasus pelanggaran berserikat yang sampai diperadilankan. Kasus-kasus yang relevan misalnya terjadi di SP Mandiri, SP Bank Panin, SP Nusantara, SPTP PT Koinus Jaya Garment, SP PT Setia Kawan Menara Motor, dsb. (http://www.hukumonline.com/detail.asp?id= $18838 \& \mathrm{cl}=$ Berita $)$.

Kedua, Undang-Undang Nomor 13/2003 Tentang Ketenagakerjaan. Setelah diundangkan-nya UU ini, terdapat 4 Pasal yang dilakukan perubahan, yaitu Pasal 159, Pasal 170, Pasal 171, dan Pasal 172. Perubahan Pasal 159 yang semula terdiri atas 4 ayat, diubah menjadi 1 ayat, sedangkan Pasal-Pasal lainnya hanya mengalami perubahan redaksional. Hasil kajian akademis yang dilakukan oleh Tim Akademik dari 5 PTN terhadap UU ini terkait dengan hubungan industrial merekomendasikan agar: 1) Pemerintah perlu mendorong terciptanya iklim hubungan timbal balik antara pekerja/buruh dan majikan/ pengusaha yang kondusif dalam melaksanakan perundingan koleketif pada tingkat Bipartit dan 2) Pemerintah perlu menetapkan ketentuanketentuan hukum yang mendorong terlaksananya perundingan kolektif yang harmonis antara pekerja/buruh dan majikan/pengusaha dengan dilandasi prinsip-prinsip perilaku beretikad baik (code of good faith). Di samping itu, diperlukan juga sikap yang arif dan bijaksana, sikap kedewasaan dalam berorganisasi, serta mengedepankan sikap kejujuran dari masing-masing pihak dalam penyelesaian perselisihan kepentingan.

Ketiga, Undang-Undang Penyelesaian Perse- lisihan Hubungan Industrial. Pada bagian terakhir dalam UU Perburuhan yang dikelompok-kan menjadi 3 paket dan merupakan turunan dari UU Nomor 25/ 1997 adalah UU Penyelesaian Perselisihan Hubungan Industrial (PPHI). Perubahan besar yang akan terjadi jika diberlakukan UU tersebut yaitu menghilangkan bentuk perselisihan perburuhan yang istimewa berbeda dengan perselisihan lainnya. Sesuai hakikat hubungan perburuhan yaitu tidak seimbangnya posisi antara pekerja/buruh dengan majikan, perselisihan perburuhan selama ini dibuatnya secara kolektif dan semi peradilan. Artinya, tidak sepenuhnya berada di bawah kekuasaan yudikatif, akan tetapi mempunyai kekuatan hukum tetap sehingga dapat dimintakan eksekusi dari peradilan (Anonim, tanpa tahun, Ringkasan Eksekutif Hasil Kajian Akademis Terhadap UU No.13 Tahun 2003 Tentang Ketenagakerjaan).

\section{Analisis Kritis}

Berkaitan dengan peraturan perundangundangan tentang ketenagakerjaan dan serikat pekerja/serikat buruh, sebenarnya Negara/ Pemerintah telah mengatur dalam beberapa hal yang masih sering menjadi konflik kepentingan antara pekerja/buruh dengan majikan/pengusaha. Konflik kepentingan tersebut antara lain terkait dengan pendirian serikat pekerja/serikat buruh, pemutusan hubungan kerja, dan sanksi pidana bagi pekerja/buruh.

Hal tersebut secara berturut-turut termaktub dalam Pasal 153 ayat (1) huruf g UU tentang Ketenagakerjaan Nomor 13, Tahun 2003 yang menyatakan bahwa"Pengusaha dilarang melakukan pemutusan hubungan kerja dengan alasan pekerja/buruh mendirikan, menjadi anggota dan/ atau pengurus serikat pekerja/serikat buruh, pekerja/buruh melakukan kegiatan serikat pekerja/serikat buruh di luar jam kerja, atau di dalam jam kerja, atas kesepakatan pengusaha, atau berdasarkan ketentuan yang diatur dalam perjanjian kerja, peraturan perusahaan, atau perjanjian kerja bersama".

Selanjutnya, Pasal 28 huruf a UU tentang Serikat Pekerja/Serikat buruh, menyatakan bahwa "Siapa pun dilarang menghalang-halangi atau memaksa pekerja/buruh untuk membentuk atau tidak membentuk, menjadi pengurus atau tidak 
menjadi pengurus, menjadi anggota atau tidak menjadi anggota dan/atau menjalankan atau tidak menjalankan kegiatan serikat pekerja/ serikat buruh dengan cara melakukan pemutusan hubungan kerja, menghentikan sementara, menurunkan jabatan, atau melakukan mutasi". Di samping itu, Pasal 43 ayat (1) UU tentang Serikat Pekerja/Serikat Buruh sebagaimana dimaksud dalam Pasal 28, dikenakan sanksi pidana penjara paling singkat satu tahun dan paling lama lima tahun dan/atau denda paling sedikit Rp 100.000.000,00 (seratus juta rupiah) dan paling banyak Rp 500.000.000,00 (lima ratus juta rupiah)

Terdapat Pasal dalam UU Nomor 13/2003 yang inkonsisten, antara lain Pasal 56 ayat (2a) versus Pasal 59 ayat (2) yang mengatur Perjanjian Kerja Waktu Tertentu (PKWT); Pasal 88 ayat (3) tentang pengaturan dasar penetapan upah minimum; Pasal 1 butir 15 versus Pasal 66 ayat (2a) yang mengatur outsourching pekerja.

Kondisi tersebut mengakibatkan perbedaan persepsi dalam menentukan upah minimum dan pengaturan PKWT yang masih menjadi masalah di kalangan pekerja/buruh. Praktik istirahat jam kerja, istirahat mingguan, cuti tahunan, dan lembur masih sering menjadi pemicu konflik antara pekerja/buruh dan majikan/pengusaha.Sekalipun pengusaha/ majikan telah mengikuti prosedur pemutusan hubungan kerja (PHK) bagi pekerja tetap, namun bagi pekerja kontrak, prosedur PHK belum sesuai dengan ketentuan. Penggunaan TKA juga masih menjadi pro-kontra karena tidak ada larangan. Pemerintahlah yang seharusnya mengatur penggunaan TKA untuk membuka pasar domestik sekaligus mengangkat potensi daerah dalam mengembangkan pemasaran produk-produk keunggulan lokal. Pada akhirnya, masih ditemukan kasus-kasus ketidakharmonisan hubungan antara pekerja/buruh dengan pengu-saha/majikan. Hal ini dapat dicermati semakin banyaknya demo-demo pekerja/buruh pabrik yang disebabkan oleh konflik kepentingan antara pekerja/buruh dengan majikan/ pengusaha.

\section{Simpulan dan Saran Simpulan}

Atas dasar uraian peran negara dalam hubungan industrial di Indonesia, dapat disimpulkan bahwa Negara telah cukup banyak menghasilkan produk- produk hukum terkait dengan hubungan kerja antara pekerja/buruh dan majikana/pengusaha, namun dalam implementasinya. Pemerintah belum memihak kepada kaum dzuafa/lemah (pekerja/buruh).

Sebagai salah satu indikator bahwa akhir-akhir ini terjadi pemilihan pengurus Serikat Pekerja/Serikat Buruh sebagian besar bukan berasal dari Serikat Pekerja/Serikat Buruh, sehingga dalam memperjuangkan hak-hak pekerja/buruh seringkali tidak membawa hasil sesuai yang diharapkan. Di samping itu, berbagai perundingan penyelesaian atau konflik antara pekerja/buruh dan majikan/pengusaha kebebasan berserikat dan berpendapat tidak sepenuhnya diberikan kepada pekerja/buruh. Dengan kata lain, sekalipun produk undang-undang terkait dengan serikat pekerja/buruh telah diimplementasikan, akan tetapi masih terjadi ketidakkonsistenan pelaksanaan.

Pemerintah dalam mengimplementasikan Pasal-Pasal, yaitu Pasal 56 ayat (2a) dengan Pasal 59 ayat (3) yang mengatur dasar penetapan upah minimum. Kemudian Pasal 1 butir 15 dengan Pasal 66 ayat (2a) yang mengatur outsourching pekerja. Ketidakkonsistenan pasal-pasal tersebut mengakibatkan ketidakefektifan pasal-pasal yang mengatur hak berserikat dan hak atas jaminan social bagi pekerja PKWT dan outsourching. Di samping itu, ditemukan pula pasal yang menghambat proses efisiensi perusahaan karena alasan ekonomi yaitu Pasal 164 ayat (3).

Dalam menyelesaikan konflik antara pekerja dengan majikan (pengusaha) masih belum terselesaikan secara proporsional, sehingga seringkali pihak tenaga kerja merasa dirugikan. Hal ini terutama penyelesaian masalah tenaga kerja di luar negeri yang memang secara faktual adakalanya pihak Penyalur Jasa Tenaga Kerja Indonesia (PJTKI) kurang bertanggung jawab dalam aspek kelengkapan dokumen dan seleksi keterampilan fungsional yang dimiliki oleh calon pencari kerja di Indonesia.

\section{Saran}

Atas dasar simpulan tersebut maka disarankan agar: 1) Kemdiknas dan Kemnakertrans meningkatkan koordinasi dan kolaborasi khususnya kewenangan pendidikan dan pelatihan bagi kedua kementerian khususnya dalam kejelasan dan kepastian kewenangan menyiapkan tenaga kerja yang siap berkompetisi dan memiliki kompetensi yang sesuai 
dengan tuntutan dunia kerja; 2) Pemerintah melalui DPR RI perlu melakukan pengawasan dan supervisi implementasi setiap peraturan perundang-undangan terkait dengan ketenagakerjaan di Indonesia; 3) Kemnakertrans perlu melakukan pembinaan dan meningkatkan koordinasi dengan pimpinan Serikat Pekerja/Buruh sehingga tercipta iklim kerja yang kondusif dan harmonis dalam tata hubungan kerja secara kelembagaan; 4) Pemerintah perlu berupaya terus-menerus dalam upaya menertibkan PJTKI agar pengiriman tenaga kerja Indonesia ke luar negeri benar benar sesuai dengan prosedur dan persyaratan kerja yang berlaku; dan.5) Kemnakertrans perlu meningkatkan kerja sama dengan Kementerian/ Instansi terkait lainnya seperti Badan Koordinasi Penanaman Modal (BKPM); Kementerian Luar Negeri (terkait dengan urusan izin tinggal/bekerja orang asing di Indonesia), Kementerian Kelautan terkait dengan Sertifikasi Profesi tenaga Pelayaran (sertifikat IMO)

\section{Pustaka Acuan}

A.S Finawati, tanpa tahun, dalam $h t t p: / / w w w . ~ p e m a n t a u a n$ peradilan.com, diakses pada tanggal 31 Maret 2009.

Anonim, tanpa tahun, Ringkasan Eksekutif Hasil Kajian Akademis Terhadap UU No.13 Tahun 2003 Tentang Ketenagakerjaan

Anonim, tanpa tahun, Teori Hubungan Industrial, diakses pada tanggal 27 Januari 2009

Anonim, tanpa tahun, Organisasi Buruh Internacional (ILO) Biro Pendidikan Pekerja (Actrav): ILO dan Pekerja

Anonim,tanpa tahun, Gabungan Federasai Serikat Pekerja/Serikat Buruh, 20 Februari 2008

Anonim, http://www. (ppi) (ppiindia), Pentingnya Serikat Buruh, diakses pada tanggal 31 Maret 2009

Blog at WordPress.com, diakses pada tanggal 29 Oktober 2009

http://www.hukumonline.com/detail.asp?id=18838\&cl=Berita, diakses pada tanggal 26 Januari 2009.

http://survey07.ituc-csi.0rg/getcountry.pnp?IDLang=EN\&IDCountry=IDN\&ID Supp $=\ldots 18 / 10 / 2008$, diakses pada tanggal 26 Januari 2009

Keputusan Menteri Tenaga Kerja, Nomor 648/Men/1985 tentang Pelaksanaan Hubungan Industrial Pancasila Kompas, Politik Perburuhan yang "Amburadul", 6 Maret 2000, diunduh tanggal 29 Januari 2009

Undang-Undang Dasar Negara Republik Indonesia Tahun 1945 (Hasil Revisi Pertama)

Undang-Undang Nomor 25 Tahun 1997 Tentang Ketenegakerjaan

Undang-Undang Republik Indonesia Nomor 13 Tahun 2003 tentang Ketenagakerjaan, Jakarta.

Undang-Undang Nomor 14 Tahun 1969 Tentang Ketentuan-Ketentuan Pokok Mengenai Tenaga Kerja

Undang-Undang Republik Indonesia Nomor 21 Tahun 2000 tentang Serikat Pekerja/Serikat Buruh, Jakarta.

Undang-Undang Dasar Republik Indonesia Nomor 39 Tahun 1999 Tentang Hak-Hak Asasi Manusia (HAM)

Undang-Undang Republik Indonesia Nomor 20/1999. Ratifikasi konvensi ILO No. 38 Tentang usia minimum yang diperbolehkan bekerja

Undang-Undang Nomor 1/1951 tentang Pernyataan Berlakunya UU Nomor 12/1948 Tentang Kerja; Undang-Undang Nomor 2/1951 tentang Berlakunya UU Nomor 33/1947 Tentang Kecelakaan Kerja Undang-Undang Nomor 3 /1951 Tentang Pernyataan Berlakunya UU Nomor 23/1948 Tentang Pengawasan Perburuhan;

Undang-Undang Nomor 21/1954 Tentang Perjanjian Perburuhan antara Serikat Buruh dan Majikan; Undang-Undang Nomor 18/1956 Tentang Persetujuan Konvensi ILO No. 98 mengenai berlakunya Dasar-dasar dari hak untuk berorganisasi dan untuk berunding bersama.

Undang-Undang Nomor 22/1957 Tentang Penyelesaian Perselisihan Perburuhan;

Undang-Undang Nomor 3/1958 Tentang Penempatan Tenaga Asing;

Undang-Undang Nomor 12/1964 Tentang Pemutusan Hubungan Kerja di Perusahaan Swasta. 